\title{
Ethylene Production of Heat-treated Stem Tissues of Red-osier Dogwood at Several Growth Stages
}

\author{
A.M. Shirazi', L.H. Fuchigami ${ }^{2}$, and T.H.H. Chen ${ }^{2}$ \\ Department of Horticulture, Oregon State University, Corvallis, \\ OR $\quad 97331-7304$
}

Additional index words. ACC, ecodormancy, endodormancy, heat stress, IAA, methionine, Cornus sericea

\begin{abstract}
Ethylene production in stem tissues of red-osier dogwood (Cornus sericea L.) following heat treatment was determined at several growth stages. Ethylene production of heat-stressed stem tissue depended on the stage of development and was a function of the degree of stress. During active growth and early endodormancy, heat stress of stem tissues stimulated ethylene production, reaching a peak at $40 \mathrm{C}$, followed by a steady decrease at higher temperatures. Highest ethylene levels from stressed tissues occurred in May, July, September, and March. Only a trace amount of ethylene was produced during endodormancy to ecodormancy (late October to January) from stressed and nonstressed stem tissues. Applying ACC to stem segments at late endodormancy (December) or applying methionine and IAA to stem segments at maximum endodormancy (November) enhanced ethylene production of both nonstressed and heat-stressed stem tissues. Chemical names used: $1 \mathrm{H}$ - indole-3-acetic acid (IAA); 1-aminocyclopropane-1-carboxylic acid (ACC).
\end{abstract}

Ethylene production has been associated with many types of stresses in plant tissue (Abeles, 1973). Generally, ethylene production in plants increases in response to increasing stresses up to a certain point (sublethal stress) and decreases thereafter (Field, 1981, 1985; Harber and Fuchigami, 1986; Kobayashi et al., 1981; Leopold et al., 1972). The relationship of high temperature and ethylene production is not well known in plants. Yu et al. (1980) indicated that the optimal temperature for ethylene production in hypocotyls of mung bean [Vigna radiata (L.) R. Wilcz.] and plugs of apple (Malus domestica Borkh. 'Golden Delicious') was 30C, and that higher temperatures (35 to 40C) inhibited ethylene production in other plant tissues. Hosoki (1984) reported that hot water treatment (46C for $1 \mathrm{~h}$ ) had no significant effect on ethylene production in dormant corms of gladiolus (Gladiolus L. spp. 'Traveler') and bulbs of Easter lily (Lilium longiflorum L. 'Hinomoto'). Ethylene production decreased during dormancy development in deciduous plants (Seibel and Fuchigami, 1978), and its concentration decreased in the wood of coniferous trees (Barbro et al., 1991).

The suggested pathway of stress ethylene

\footnotetext{
Received for publication 30 Nov. 1992. Accepted for publication 11 June 1993, Oregon Agricultural Experimental Station Technical paper no. 10090. The cost of publishing this paper was defrayed in part by the payment of page charges. Under postal regulations, this paper therefore must be hereby marked advertisement solely to indicate this fact. 'Postdoctoral Research Associate. Present address: Dept. of Botany and Plant Pathology, Oregon State Univ., Cordley Hall 2082, Corvallis, OR 973312902.

${ }^{2}$ Professor,
}

biosynthesis is from methionine, which metabolized to $S$-adenosylmethionine (SAM), to ACC, then to ethylene (Yang and Hoffman, 1984). ACC synthase, which converts SAM to ACC, is a key enzyme in ethylene biosynthesis, and ethylene-forming enzyme (EFE), which converts ACC to ethylene, was thought to be membrane-bound (Kende, 1989). EFE activity was suspected to be related to membrane integrity (Kende, 1989). However, Ververidis and John (1991) recently demonstrated recovery of EFE activity in vitro and suggested that EFE was a soluble enzyme perhaps loosely bound to membranes.

IAA also stimulates ethylene production in plants (Yoshi and Imaseki, 1982). Auxin-induced ethylene production is due to enhanced ACC-synthase activity (Yoshi and Imaseki, 1982). Therefore, the objective of this study was to investigate the relationship of heat stress and ethylene production in stem tissues of red-osier dogwood at several growth stages for near-lethal (sublethal) studies. In previous studies, we reported the possible relationship of ethylene production in overcoming endodormancy of buds by exposure to sublethal stress (Fuchigami and Nee, 1987).

A clone of red-osier dogwood from Wayland, Mass., was used for these studies. The growth stages of the plants were determined by the ${ }^{\circ} \mathrm{GS}$ model (Fuchigami et al., 1982). The plants were propagated vegetatively by single-node stem cuttings in Feb. 1988. Rooted cuttings were transplanted into a pasteurized medium of 1 fir bark: 1 peat: 1 soil (by volume) in $1150-\mathrm{cm}^{3}(15-\mathrm{cm})$ fiber pots, and grown in a lathhouse with $20 \%$ shade. Plants were irrigated by overhead sprinklers twice daily (6:00 AM and 3:00 PM). Osmocote (17N-6P-9K) (Grace/Sierra Co., Milpitas, Calif.) with micronutrients was applied at $4 \mathrm{~g} / \mathrm{pot}$ at planting. Plants were trained to one stem in June and July and were 70 to $90 \mathrm{~cm}$ tall at the time of the experiments.

Five detached, 50-cm-long defoliated stems were placed in individual Saran bags (Du Pont Co., Wilmington, Del.), the air evacuated, and the bags sealed to prevent water entry. Bags were then placed in a water bath and exposed to either $30,35,40,45,50,55$, or $60 \mathrm{C}$ for $1 \mathrm{~h}$ at each test temperature. Controls were held at room temperature $(23 \pm 3 \mathrm{C})$. After heat treatment, $2.5-\mathrm{cm}$ internodal stem segments were cut from the second, third, and fourth internodes from the proximal portions of the stems. For ethylene measurement, five internode samples were selected randomly, placed in a scintillation vial, closed with a serum stopper, and incubated for $8 \mathrm{~h}$ in darkness. One-milliliter samples were drawn from the vials and injected into a Carle 211 gas chromatography (Carle, Fullerton, Calif.) equipped with a 1.22 $\mathrm{m} \times 3.8-\mathrm{mm} 80 / 100$ mesh-activated alumina column with a flame ionization detector. The flow rate was $20 \mathrm{ml} \cdot \mathrm{min}^{-1}$, and the column and detector were at $80 \mathrm{C}$.

To determine whether ACC was limiting in dormant tissues, internode samples (heat treated and controls) were treated with either $0.25 \mathrm{ml} 10 \mathrm{~mm}$ ACC (Sigma Chemical Co., St. Louis) or double-distilled water on 4 Dec. 1988, and shaken on an orbital shaker at 100 rpm for $1 \mathrm{~h}$ in darkness at $25 \mathrm{C}$. To determine if methionine or IAA stimulated ethylene production in dormant tissues, internode samples (heat treated and controls) were treated with $0.25 \mathrm{ml} 100 \mathrm{~mm}$ methionine [or $10 \mathrm{~mm}$ IAA (both, Sigma)] or double-distilled water on 8 Nov. 1989, and shaken on an orbital shaker at $100 \mathrm{rpm}$ for $18 \mathrm{~h}$ in darkness at 25C. Samples were blotted dry and placed individually into scintillation vials as described above. Samples were incubated for 8 and $24 \mathrm{~h}$ and ethylene measurements taken as described previously. All experiments followed a completely randomized design.

Ethylene production of nonstressed (controls) and heat-stressed internodal stem tissues varied with sampling date (Fig. 1). Controls produced more ethylene during the active growth period (March to July) than during the dormant period (September to January). During early endodormancy (September and early October), ethylene production increased with increasing heat stress, peaking at $40 \mathrm{C}$ and decreasing sharply at $45 \mathrm{C}$. From the middle stages of endodormancy through ecodormancy (late October to January), heat stress had no effect on ethylene production. In March, when spring budbreak occurred, increasing heat stress caused ethylene production to decrease. During May and July, heat stress promoted stress ethylene production, increasing to a peak at $\approx 40 \mathrm{C}$ and decreasing sharply at $45 \mathrm{C}$ (Fig. 1).

Applying ACC to internodal stem sections in Dec. 1988 promoted ethylene production in the heat-stressed (30 to 45C) tissues (Fig. 2A), In contrast, tissues not treated with ACC produced low concentrations of ethylene $(\approx 1$ $\mathrm{nl} \cdot \mathrm{g}^{-1} \cdot \mathrm{h}^{-1}$ ) in all stress treatments (Fig. 2A). Stems treated with methionine and incubated 


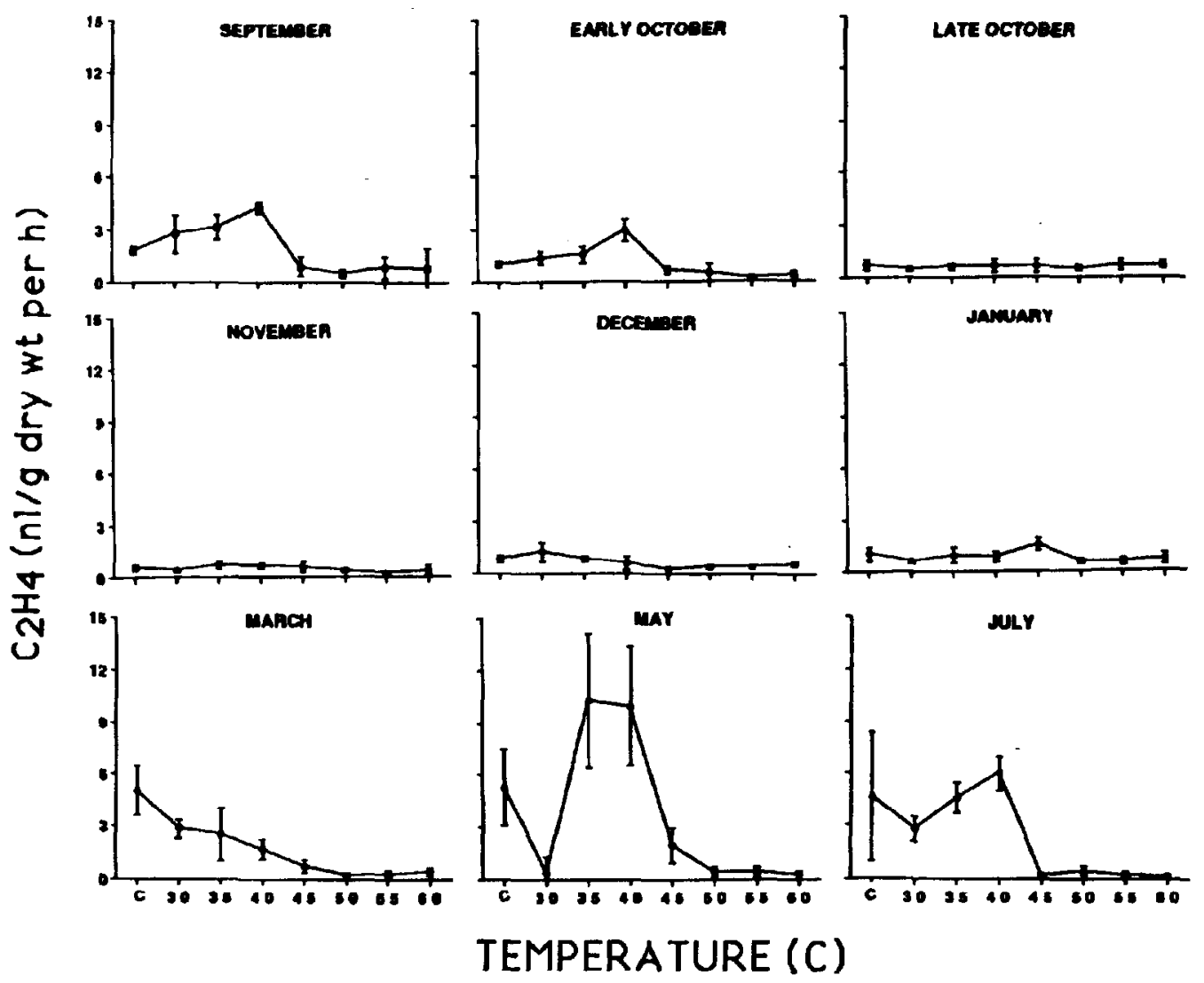

Fig. 1. Ethylene production in stem tissues of red-osier dogwood at several sampling times. Vertical bars represent $\pm 1 \mathrm{sD}(\mathrm{n}=5)$. C $=$ control, $23 \pm 3 \mathrm{C}$.

for $8 \mathrm{~h}$ produced more ethylene than the controls from 30 to $45 \mathrm{C}$, and when incubated for $24 \mathrm{~h}$ produced more ethylene from 30 to $50 \mathrm{C}$ than the controls (Fig. 2B). A significant difference between 8 - and 24-h incubation was observed only for samples treated at 45 or $50 \mathrm{C}$ (Fig. 2B). The control samples treated with methionine also produced substantial amounts of ethylene. In contrast, nontreated tissues produced low levels of ethylene $(\approx 0.5$ $\mathrm{nl} \cdot \mathrm{g}^{-1} \cdot \mathrm{h}^{-1}$ ) in all treatments (Fig. 2B).

Stems treated with IAA and incubated for 8 and $24 \mathrm{~h}$ produced more ethylene than the controls from 30 to $45 \mathrm{C}$ (Fig. 2C). The effect of incubation time was significant only at $45 \mathrm{C}$ (Fig. 2C). The control samples treated with IAA also produced substantial amounts of ethylene. In contrast, nontreated tissues produced very low levels of ethylene $\left(\approx 0.5 \mathrm{nl} \cdot \mathrm{g}^{-1} \cdot \mathrm{h}^{-1}\right)$ in all treatments (Fig. 2C).

Production of stress ethylene has also been shown to depend on plant growth status (Barbro et al., 1991; Seibel and Fuchigami, 1978). Typically, increased stress causes increased ethylene production in plant tissue; ethylene levels reach a peak, and then decrease until the tissue is killed (Field, 1985; Harber and Fuchigami, 1986). Because the rate of ethylene production changes with stress treatment, this feature has been used as a measure of stress and injury to plant tissues. Increased ethylene production is thought to relate to the degree of nonlethal stress to which the tissues are exposed. Following the peak in ethylene, further stress caused ethylene production to decrease, and this decrease correlates inversely with increases in membrane permeability and ethane production (Harber and Fuchigami, 1986).

Our results reflect the typical bell-shaped curve of ethylene production with increasing levels of heat stress during the active growth period (March to July) and during early endodormancy (September and early October). During the middle stages of endodormancy and ecodormancy (late October to January), heat stress of stem tissues had no effect on ethylene production. Barbro et al. (1991) suggested that reduced ethylene concentration in Scotch pine (Pinus sylvestris L.) during winter is due to decreased temperature and decreased metabolic activity.

Applying ACC in December and methionine and IAA in November to stem tissues following heat-stress treatments promoted ethylene production. The concentration of ethylene produced was not due to heat stress, as the control tissues without heat stress produced ethylene concentrations similar to the heatstressed tissues. The bell-shaped curve, which typifies stress ethylene production, was not observed with increasing heat stress. Methionine has been shown to decrease in poplar (Populus gelrica L.) (Sagisaka, 1972) and stem tissues of red-osier dogwood (Li et al., 1965) during dormancy. Thus, these studies suggest that reduced ethylene concentration in dormant tissues is due to reduced substrate concentration rather than a lack of enzyme activity required for ethylene production from methionine. Fuchigami and Nee (1987) reported that ethylene induced by sublethal stresses was involved in breaking endodormancy. Failure of endodormant tissues to produce ethylene following exposure to sublethal stress suggests that ethylene may not be involved in breaking endodormancy.

\section{Literature Cited}

Abeles, F.B. 1973. Ethylene in plant biology. Academic, New York.

Barbro, S., M. Ingemarsson, E. Lundqvist, and L. Elliasson. 1991. Seasonal variation in ethylene concentration in the wood of Pinus sylvestris L. Tree Physiol. 8:273-279.

Field, R.J. 1981. A relationship between membrane permeability and ethylene production at high temperature in leaf tissue of Phaseolus vulgaris L. Ann. Bot. 48:33-39.

Field, R.J. 1985. The effect of temperature on the ethylene production by plant tissues, p. 47-69. In: J.A. Roberts and G.A. Tucker (eds.). Ethylene and plant development. Butterworths, Boston.

Fuchigami, L.H. and C.C. Nee. 1987. Degree growth stage model and rest breaking mechanisms in temperate woody perennials. HortScience 22:836-845.

Fuchigami, L.H., C.J. Weiser, K.D. Kobayashi, R. Timmis, and L.V. Gusta. 1982. A degree growth stage $\left({ }^{\circ} \mathrm{GS}\right)$ model and cold acclimation in temperate woody plants, p. 93-116. In: P.H. Li and A. Sakai (eds.). Plant cold and freezing stress. Academic, New York.

Harber, R.M. and L.H. Fuchigami. 1986. The relationship of ethylene and ethane production to tissue damage in frozen rhododendron leaf disks. J. Amer. Soc. Hort. Sci. 111:434-436.

Hosoki, T. 1984. Effect of hot water treatment on respiration, endogenous ethanol, and ethylene 


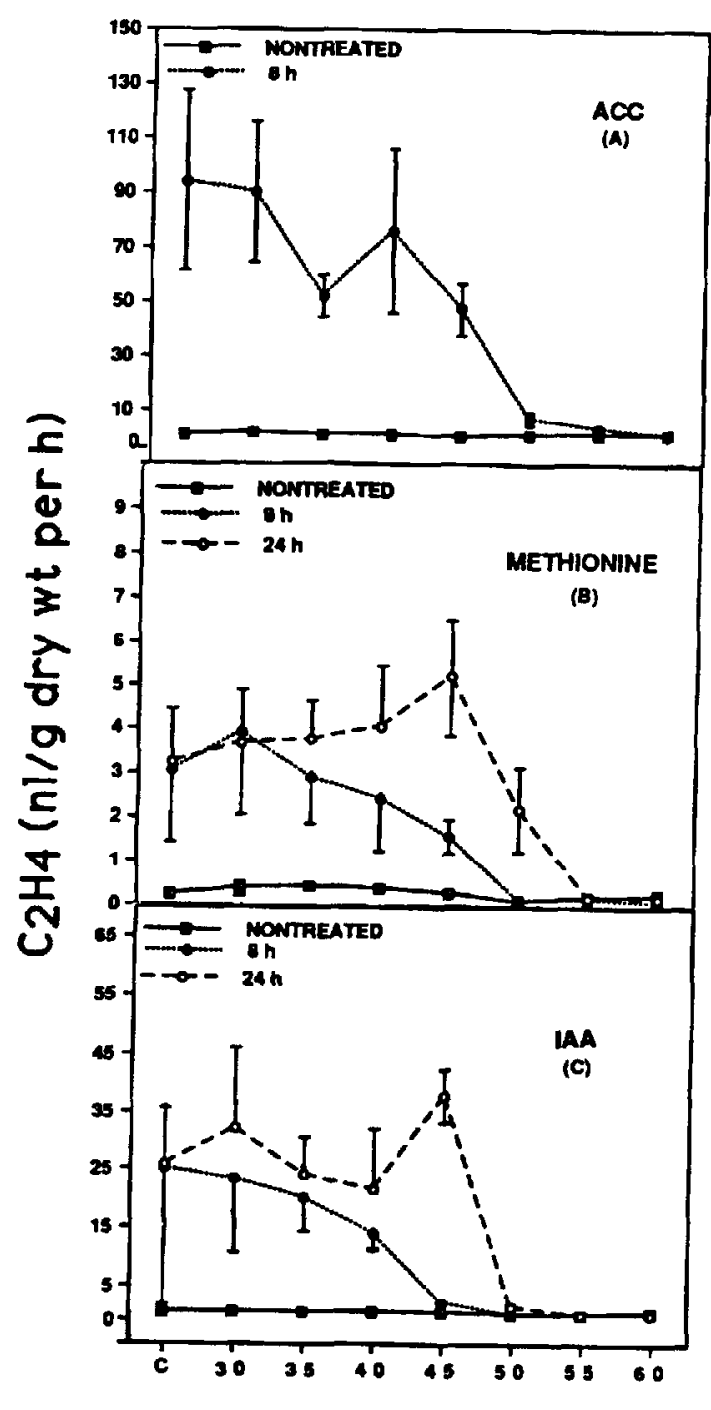

TEMPERATURE (C) production from gladiolus corms and Easter lily bulbs. HortScience 19:700-701.

Kende, H. 1989. Enzymes of ethylene biosynthesis. Plant Physiol. 91:14.

Kobayashi, K.D., L.H. Fuchigami, and K.E. Brainerd. 1981. Ethylene and ethane production and electrolyte leakage of water stressed 'Pixy' plum leaves. HortScience 16:57-59.

Leopold, A.C., K.M. Brown, and F.H. Emerson. 1972. Ethylene in the wood of stressed trees. HortScience 7:175.

Li, P.H., C.J. Weiser, and R. Van Huystee. 1965. Changes in metabolites of red-osier dogwood during cold acclimation. J. Amer. Soc. Hort. Sci. 86:723-730.

Sagisaka, S. 1972. Decrease of glucose 6-phosphate and 6-phosphogluconate dehydrogenase activities in the xylem of Populus gelrica on budding. Plant Physiol. 50:750-755.

Seibel, J.R. and L.H. Fuchigami. 1978. Ethylene production as an indicator of seasonal development in red-osier dogwood. J. Amer. Soc. Hort. Sci. 103:739-741.

Ververidis, P. and P. John. 1991. Complete recovery in vitro of ethylene-forming enzyme activity. Phytochemistry 3:725-727.

Yang, S.F. and N.E. Hoffman. 1984. Ethylene biosynthesis and its regulation in higher plants. Annu. Rev. Plant Physiol. 35: 155-189.

Yoshi, H. and H. Imaseki. 1982. Regulation of auxin-induced ethylene biosynthesis. Repression of inductive formation of 1-aminocyclopropane-1-carboxylate synthase of ethylene. Plant Cell Physiol. 23:639-649.

Yu, Y.B., D.O. Adams, and S.F. Young. 1980 Inhibition of ethylene production by 2,4 ,-dinitro phenol and high temperature Plant Physiol. 66:286-290.

Fig. 2. Effect of (A) $10 \mathrm{~mm}$ ACC, (B) 100 mm methionine, and (C) $10 \mathrm{~mm} \mathrm{IAA}$ after 8- and/or 24-h incubation on ethylene production of heat-treated stem tissues of red-osier dogwood. Vertical bars represent $\pm 1 \mathrm{SD}$ $(\mathrm{n}=5) . \mathrm{C}=$ control, $23 \pm 3 \mathrm{C}$ 